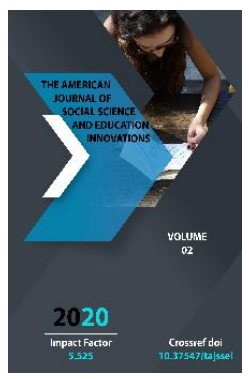

\title{
The Concept And Specifics Of Joint Activity In Civil Law
}

\author{
Dadaboev Abdullo Khaydaralievich \\ Employee Of The Department Of Justice Of Shahrikhan District Of Andizhan Region, Republic \\ Of Uzbekistan, Uzbekistan.
}

Journal Website:

http://usajournalshub.c

om/index,php/tajssei

Copyright: Original

content from this work

may be used under the

terms of the creative

commons attributes

4.0 licence.

\section{ABSTRACT}

The article discusses the concept of joint activities and the legal basis for its implementation, as well as existing methods and approaches. The author analyzes the issues of joint activities in civil law with and without a legal entity and comes to the conclusion that the main criterion is that the partners do all the work by mutual consent.

\section{KEYWORDS}

Civil law, joint venture, commercial company, full company, common company, contract, mutual agreement, agreement, partner.

\section{INTRODUCTION}

The implementation of socio-economic activities by entities may not always yield the expected results. Therefore, in carrying out economic activities, individuals strive to achieve an optimal result for themselves by combining power and investment. The joint activity of individuals may be carried out in any sphere of social life not prohibited by law. To do this, they are allowed to use either the existing legal constructions provided for in the legislation or methods that do not exist in the legislation but do not contradict it.

In civil law, joint activities are carried out in different ways and means. For example, if a business may be carried out jointly by individuals with or without a legal entity, they may carry out joint activities by entering into a contract under civil law.

\section{METHODS}


Joint activity with the formation of a legal entity may be carried out in the form of a full partnership and a limited partnership of a legal entity established by the Civil Code of the Republic of Uzbekistan. In this case, joint activity means personal participation of partners in direct activities, participation in the conduct of activities. Of course, it is possible to run a business as a partner by combining capital and get some income from it. However, this situation cannot be considered as a joint activity in the pure sense, because the joint activity is embodied as an action of a person with other persons, which is carried out on the basis of his direct personal participation and labor. This raises the problem of assessing the activities of individuals in the form of a company as a joint venture from a legal point of view. This is because the so-called partners act on behalf of a single entity after forming a legal entity and becoming its participant, and it is debatable whether their activities can be considered as joint activities of two or more persons.

\section{RESULTS AND DISCUSSIONS}

Focusing on the issue of companies in preSoviet Turkestan, H.R. Rahmonkulov states that company contracts were divided into two types: “company milk', for example a company based on the joint ownership, use and disposal of common property by two or more persons and "company akid" i.e. a joint agreement [3].

In our opinion, the company has acted as a way for people to work together. The word company is derived from Arabic and means partnership, association, and is a partnership of friends, a voluntary association of people united to carry out a certain work together [5]. In short, the term company was used in the sense of running a profit-making activity in a partnership.

According to S. Iskhakov, "company" is an Arabic word that means "add", "mix" in the dictionary . This type of company is called a voluntary company.

To date, the term "company" is used in the legislation as a type of organizational and legal form of a legal entity, as well as a separate type of civil contract. The definition of a "company" as a legal entity in the national legislation of Uzbekistan can be associated primarily with the maintenance of the tax and accounting system in the continental legal system. At the same time, there are specific advantages and disadvantages of conducting a joint activity or, in other words, a business partnership, as a legal entity. Therefore, the legislation also provides an opportunity to carry out joint activities without the formation of a legal entity. Such a dualistic approach, while complicating the partnership in setting up and running a business, creates certain hesitations for co-operators. Therefore, it is important to optimize the civil law structure of joint activities and create a system that is convenient for those who want to do business together. But in any case, and the company is based on an agreement between the parties. After all, working together and doing business is required to be based on mutual agreement of partners. Such an agreement shall specify the size and amount of the partners' participation and participation, who will receive how much profit, and how the liability for the joint venture obligations and the costs to be incurred will be distributed.

If we pay attention to the legislation regulating the relations related to the organization and conduct of joint activities, we can see that the current $C C$ provides for the rules of full company and limited partnership for the implementation of joint 
activities in the form of a legal entity. In particular, according to the first part of Article 60 of the Civil Code, a company is a full company in which the participants are engaged in business activities on behalf of the company in accordance with the contract between them and are liable for its obligations with all their property.

The most important and primary basis for establishing a company is the agreement between the participants. The legislation does not specify the legal nature of this agreement. However, based on the analysis of the norms of the law, it can be understood that this agreement is a memorandum of association of the participants of the company, which provides for the conditions of formation and operation of the company. According to V.R. Topildiev, according to the memorandum of association, the founders undertake to establish a legal entity, determine the order of joint activities for its establishment, the transfer of its property and the conditions of participation in its activities [4].

According to L.I. Barsukova, it is necessary to distinguish between the memorandum of association and the agreement on the establishment of a legal entity. The memorandum of association and the agreement on the establishment of a legal entity are close in nature, but if the memorandum of association is a constituent document of a legal entity, the agreement on the establishment of a legal entity is not included in such documents. Therefore, joint activities carried out by the founders of a legal entity can be carried out both under the founding agreement and under the agreement on the establishment of the legal entity until the state registration of the legal entity [1].

In our opinion, a contract concluded between the participants of a full company is expedient to be recognized as a memorandum of association. Because through this agreement, the parties agree to work together in the future as a legal entity. The memorandum of association of a business company must contain the following: the type of business company to be established, its field of activity, goals and terms; composition of founders (participants); firm name and postal address of the established business company; the amount of the authorized fund (authorized capital) and the procedure for its formation; the amount and nominal value of the share of each participant of the business company; the composition of the shares of the participants of the business company, the terms and procedure for their contribution; the order of increase and decrease of the authorized fund (authorized capital) of the business company; the procedure for managing the activities of the business company; the order of distribution of profits and compensation of losses; the order of reorganization and liquidation of the business company; other conditions that do not contradict the legislation (Part 1 of Article 4 of the Law of the Republic of Uzbekistan "On Business Companies").

According to experts, the company defines five important criteria for full recognition: 1 ) it should be based on a contract between the participants; 2) a full company is formed for entrepreneurial activity, ie it is a commercial organization; 3) personal participation of all partners in the activities of the full company; 4) entrepreneurial activity is carried out on behalf of the company - a legal entity; 5) the participants of the company are liable for its obligations with the property belonging to them [6].

In addition, it should be noted that a full company, which is a specific legal structure for the implementation of joint activities, requires participants not only to make a certain investment in the company's activities, but 
also to participate in its activities with their own participation. Therefore, the name of such a company is called in full and all members will have to carry out the activities of the company together.

The participants of a business company undertake to work together on the basis of a contract concluded by them, and these obligations are expressed in the joint performance of work on behalf of the company. Each member of the company has the right to act on behalf of the company, if the memorandum of association does not stipulate that the company's affairs are to be conducted jointly by all its participants, or the proceedings are not entrusted to individual participants.

Agreements play an important role in working together, including doing business together. The conclusion and implementation of transactions on behalf of the company is determined by mutual agreement of the partners. In the absence of such an agreement, the consent of all participants of the company is required for the implementation of each transaction when the company's affairs are conducted jointly by its participants. If the conduct of the company's affairs is entrusted to one or more of its participants, the remaining participants must obtain a power of attorney from the participant (participants) entrusted with the conduct of the company's affairs in order to execute transactions on behalf of the company.

\section{CONCLUSION}

Another civil law construction in civil law is a simple company contract. In this case, the parties agree to work together by mutual agreement. For example, they can share the work that needs to be done to run a business together. Suppose 3 people come to run a business together. One of them may stipulate in the contract that the product will be delivered abroad on a contractual basis, the second will find buyers for the imported product and enter into agreements with them, and the third will carry out settlement work. This design has a number of advantages over running a business for 1 person. In particular, the process of carrying out such work will be easier and faster as a result of the division of work to be done by 1 person between two or more persons. In addition, partners will be able to reap greater benefits by combining their investments and efforts in carrying out their common work. Activate on joint work, conclusion of agreements with third parties and fulfillment of general obligations will have to be carried out by mutual agreement of the partners. After all, such an order is the main and main criterion of joint activity. This is because the essence of the partnership is to act on the basis of mutual agreement and thus achieve a beneficial and acceptable socio-economic effect for them.

\section{REFERENCES}

1. Barsukova L.I. Civil law characteristics of constituent documents: Abstract of thesis for the degree of Candidate of juridical sciences. - Moscow, 2013 -p.1213.

2. Iskhakov S.A. Fundamentals of Islamic Civil Law: A Textbook. - Tashkent: Academy of the Ministry of Internal Affairs of the Republic of Uzbekistan, 2005. - p. 84-85.

3. Rahmonqulov H.R. Subjects of civil law. Study guide. - Toshkent: TSJI, 2008. - p. 50-51.

4. Topildiev V.R. Theoretical and practical problems of the formation of civil organizational and legal relations. Tashkent, 2011. - 9 p. 
5. Annotated dictionary of the Uzbek language / edited by A.Madvaliev. Tashkent: State Scientific Publishing House of the National Encyclopedia of Uzbekistan, 2005. - $581 \mathrm{p}$.

6. Commentary to the Civil Code of the Republic of Uzbekistan. Volume I.Tashkent: "Vector-Press" publishing house, 2010.- $142 \mathrm{p}$. 